\title{
Cadmium effects on total individual numbers, species diversity and pigments content of epiphytic diatoms growing on Myriophyllum spicatum L.
}

\author{
Ridvan Erdal Sivaci* and Aysel Sivaci \\ Department of Biology, Art and Science Faculty, Adlyaman University, 02000 Adlyaman, Turkey \\ ${ }^{*}$ Corresponding author at: Department of Biology, Art and Science Faculty, Adlyaman University, 02000 Adlyaman, Turkey. Tel.: +90.416.2231775/2073; \\ fax: +90.416.2231774. E-mail address: rsivacii@gmail.com (R.E. Sivaci).
}

\section{ARTICLE INFORMATION}

Received: 29 May 2012

Received in revised form: 01 July 2012

Accepted: 06 July 2012

Online: 30 September 2012

\section{KEYWORDS}

Diatom

Pigment

Diversity

Epiphytic

Cadmium

Myriophyllum

\begin{abstract}
This study investigated the total organism change, species richness, chlorophyll- $a$ and carotenoid changes in the floral composition, which are developed by epiphytic diatom species growing on Myriophyllum spicatum L., collected from the Gokpinar Lake (Sivas, Turkey) against the effects of cadmium. The concentrations of the cadmium $(0,2,4,6,8$, and $16 \mathrm{mg} / \mathrm{L}$ ) were used and they were exposed to heavy metal for 96 hours. The experimental set up was already assembled before the epiphytic diatoms separated from the M. spicatum. While the total organism decreased in all cadmium concentrations compared to the control group, the viability rate within the total organism decreased from 90 to \%60. Cocconeis placentula var. euglypta (Ehr.) Grun. and Gomphonema minutum Ag. were found to be dominant species in the flora. The index of diversity was determined as 0.82 in the control group. Depending on the increase in cadmium concentration, this value decreased to 0.38. Chlorophyll- $a$ and carotenoid quantities decreased with the increase of cadmium concentration.
\end{abstract}

\section{Introduction}

Myriophyllum spicatum is a submerged aquatic plant widely spread in Europe, Asia and North Africa usually lives in shallow waters with 0.50-4.57 $\mathrm{m}$ depth. It has a highly-branched structure in water and it can grow up to 0.90-3.00 $\mathrm{m}$ in depth. This plant is mentioned in the perennial plant group and has a highly cosmopolitan structure [1]. The leaves are four pieces on a single ring, and approximately $1.5-2.7 \mathrm{~cm}$ long and usually shorter than the internodiums. The bracts are simple, shorter than flowers and in 5 pieces and the petals in male flower are 2.0-2.5 $\mathrm{mm}$ and reddish in color. The fruit is nutty and in four carpels [2]. Due to these morphological characteristics, $M$. spicatum provides a great contribution to the primer productivity of the hydrophilous system by generating an important setting surface for the periphytonic diatoms [3].

Compared to the local species, the periphytic biomass is quiet high on $M$. spicatum which has excess of competitive characteristics [4]. In addition, they change their habitat complexity and enrich the species diversity of epiphytic diatoms. Due to $M$. spicatum contain low nitrogen, high cellulose and allelopathic compounds, they are not preferred as a food by other organisms and also affect the healthy development of the local species in the habitat [5]. It is known that cadmium has a toxic effect on all aquatic organisms [6-7]. They accumulate while being transferred to the upper organism groups by including in the food chain and cause a major environmental disaster. It was reported that by limiting intake of $\mathrm{Fe}^{2+}$ by plants in waters, even in trace amount, they may cause chlorosis [8]. Under natural conditions, this toxic substance is existent in specific levels with meteorological movements and the cadmium pollution reaches to dangerous levels due to human activity [9]. The formation of wastes with heavy metal resulting from the increasing industrialization and human activities has a direct adverse effect on the

environment. Wastes, such as mining drainages, metal industry, refineries, paints, leather industry, domestic wastes, agricultural waste, and acid rains have a great share in this adverse effect. Today, fresh water and marine resources have become inefficient or unavailable in many countries due to industrial wastes.

Majority of the algae, a primary producer in aquatic ecosystems, are the diatoms. In addition, the diatoms which are sensitive to the changes in the chemistry of the water are also good indicator for fresh water ecosystems [10] determined the water quality [11]. For this reason, at the present time, diatom communities have been used by researchers in many studies on ecotoxicology and determining water quality [12-13]. The purpose of this study is to determine the effect of different cadmium concentrations on the species diversity, total organism quantity, changes in chlorophyll- $a$ and carotenoid quantities of the diatom communities epiphytically living on $M$. spicatum. The main purpose of the study was not to take the diatoms epiphytically present on $M$. spicatum, (collecting them on the macrophyte), transfer them to the experimental environment, expose them to cadmium and investigate its effect. It was to measure the community response of the diatoms to cadmium at floral level and to determine the limits of tolerance they showed to cadmium in terms of organism quantity, diversity and pigment contents while they are in an epiphytical condition and without interfering the part of the system as per their natural form and location in the habitat.

\section{Experimental}

The epiphytic diatom samples were collected from the Gokpinar Lake (Sivas, Turkey). The cadmium sulphate $\left(\mathrm{CdSO}_{4}\right)$ was used as a metal source. 
Table 1. List of diatom species.

\begin{tabular}{|c|c|c|c|c|c|c|}
\hline \multirow{2}{*}{ Taxons } & \multicolumn{6}{|c|}{ Cadmium (mg/L) * } \\
\hline & $\mathbf{0}$ & 2 & 4 & 6 & 8 & 16 \\
\hline Cocconeis placentula var. euglypta (Ehr.) Grun. & + & + & + & + & + & + \\
\hline Diatoma mesodon (Ehr.) Kütz. & + & + & - & - & - & - \\
\hline Gomphonema minutum Ag. & + & + & + & + & + & + \\
\hline Navicula lanceolata Ehr. & + & - & - & - & + & - \\
\hline Rhoicosphenia abbreviata (Ag) (Lang.-Bert.) & + & - & + & - & - & - \\
\hline Navicula cryptocephala Kütz. & + & + & + & + & - & - \\
\hline Nitzschia palea (Kütz) W. Smith & + & - & + & + & + & + \\
\hline Gomphonema parvulum (Kütz.) Kütz. & + & + & + & + & + & + \\
\hline Hantzschia amphioxys (Ehr.)Grun. & + & + & + & - & - & - \\
\hline Nitzschia linearis W. Simith & + & + & + & - & - & + \\
\hline Diatoma vulgaris Bory & + & - & + & + & - & + \\
\hline
\end{tabular}

*+: Available; - : Absent.

Samples were placed inside glass cups that contain $1000 \mathrm{ml}$ of metal solution in different concentrations $(0,2,4,6,8$, and 16 $\mathrm{mg} / \mathrm{L}$ ) along with $100 \mathrm{~g}$ of macrophyte and diatoms on it. During the process, in order to prevent the loss of epiphytic samples, the control diatom counts, which will be used after application, from each sample macrophyte were completed for pre-determination. The epiphytic diatom samples were collected from the M. spicatum in accordance with the Round's method [14]. These phases were designed in triplicates. The $\mathrm{pH}$ values of the experiment set-ups ranged between 7 and 8 and the samples were exposed the heavy metal for a period of 96 hours in the $200 \mathrm{rpm}$ shaker at $25 \pm 2{ }^{\circ} \mathrm{C}$ room temperature and in a 12-hour light and 12-hour dark environment. In order to determine the diatoms that can be separated from the $M$. spicatum with the effect of the shaker (shaking effect), the remaining waters containing metal were individually filtered using whatman no1 paper and the diatoms separating from the epiphytic flora were obtained and these counts were deducted from the total organism quantity. At the end of a 96-hour period, the samples were taken to a bath tub and $100 \mathrm{~mL}$ water was poured on them, then the samples inside the tub were scraped with a fine-bristled brush. As a result of brushing, the diatoms, that penetrated into the water, and water were taken to these sample cups and labeled. The water samples were filtered through the whatman GF/C filter paper with the help of the Millipore and the remaining filtrate was dissolved using acetone and values for chlorophyll- $a$ and carotenoids were determined and calculated on the basis of the spectrophotometric reading [4].

The diatom samples were examined, identified and counted in slides with $40 \%$ glycerin. The diatoms were identified using the studies of Krammer and Lange Bertalot [15-18] and John et al. [19]. The "SPSS 10.0" statistical software program and Microsoft Excel 2007 were used to evaluate the obtained results.

\section{Results}

Counts were performed with the temporary slides of the epiphytic diatom samples obtained from the M. spicatum exposed to different cadmium concentrations, within the $\% 40$ glycerin, and the Cocconeis placentula var. euglypta and Gomphoneme minutum were the dominant species in terms of relative density in the experimental group (Table 1). The organism density and viability percentage were calculated for each cadmium concentration $\left(0,2,4,6,8\right.$, and $\left.16 \mathrm{mgL}^{-1}\right)$. The $\%$ 90 viability level seen in the control group decreased to $\% 60$ in the epiphytic diatoms that were exposed to a $16 \mathrm{mgL}^{-1}$ concentration (Figure 1, Table 2).

There was a decrease in both the total organism quantity and the chlorophyll- $a$ and carotenoid quantities in comparison to control group in each concentration ( $p \leq 0.05)$. While the chlorophyll quantity measured in the control group was 66.2 $\mu \mathrm{g} / \mathrm{L}$ this quantity decreased to $13.20 \mu \mathrm{g} / \mathrm{L}$ in the $16 \mathrm{mg} / \mathrm{L}$ concentration by gradually continuing its decrease (Figure 2).

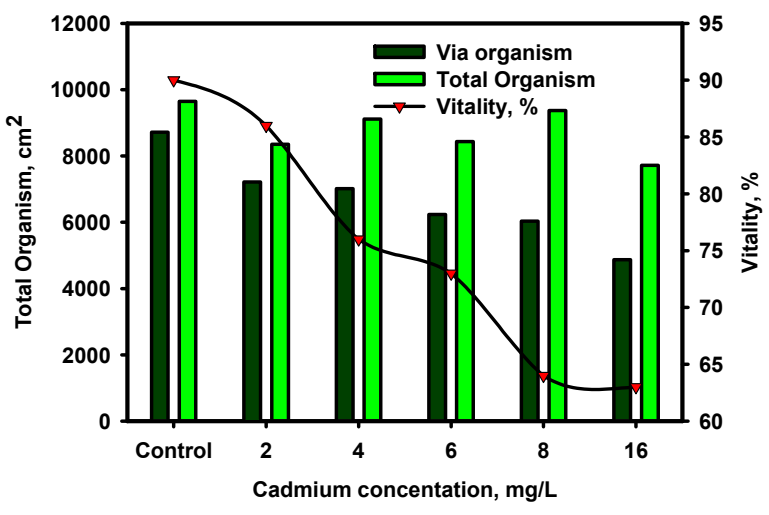

Figure 1. Total number of organisms and \% vitality.

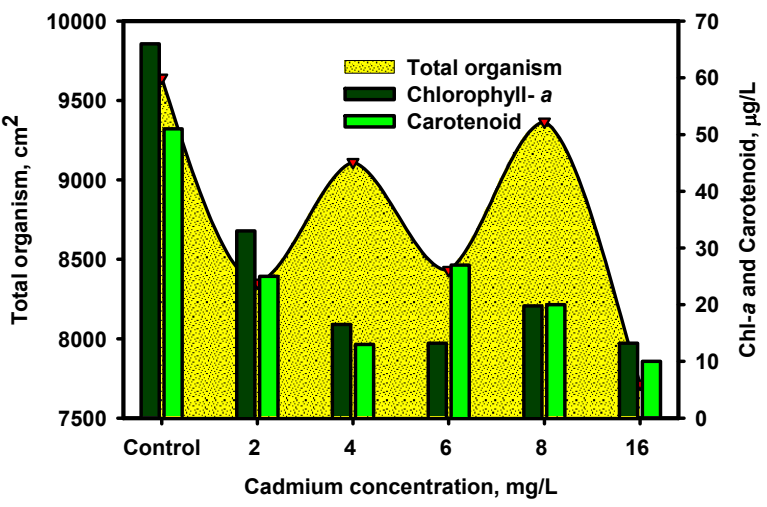

Figure 2. Chlorophyll- $a$ and carotenoid amounts according to the total number of organisms $(\mu \mathrm{g} / \mathrm{L})$.

Total organism quantities reduced gradually with the increase of concentration compared to the control group. These decreases were statistically significant $(p \leq 0.05)$ (Figure 1). Aside from the reduction in the number of organisms, the decrease in viability rate within the total organism was significant as well $(\mathrm{p} \leq 0.05)$.

At the end of the experiment, depending on the numerical values resulting from the total organism in the epiphytic diatom communities for both groups, the diversity index which includes unique individual numbers in different cadmium concentrations was performed.

$D=S-1 / \log N$

D: Margalef diversity index [20], S: number of species found, N: total number of individuals.

While the diversity level in the control group was 0.82 , this value showed a rapid decrease depending on the increase in cadmium concentration. 
Table 2. Total number of organisms and via in $\mathrm{cm}^{2}$ of epiphytic diatoms according to cadmium concentrations.

\begin{tabular}{llll}
\hline Cadmium concentrations $(\mathbf{m g} / \mathbf{L})$ & Via organism $\mathbf{( \mathbf { c m } ^ { 2 } )}$ & Total organism $\mathbf{( \mathbf { c m } ^ { 2 } )}$ & Vitality \\
\hline 2 & 7.211 & 8.353 & 86.328 \\
4 & 7.013 & 9.112 & 76.964 \\
6 & 6.237 & 8.432 & 73.968 \\
8 & 6.034 & 9.367 & 64.417 \\
16 & 4.873 & 7.716 & 63.154 \\
Control & 8.716 & 9.643 & 90.386 \\
\hline
\end{tabular}

Table 3. Margalef richness index.

\begin{tabular}{llllll} 
Control & \multicolumn{1}{l}{ Cadmium concentration (mg/L) } & & \\
\cline { 2 - 5 } & $\mathbf{2}$ & $\mathbf{4}$ & $\mathbf{6}$ & $\mathbf{8}$ & $\mathbf{1 6}$ \\
\hline 0.82 & 0.80 & 0.77 & 0.41 & 0.39 & 0.38 \\
\hline
\end{tabular}

It fell to a low level of 0.38 in the $16 \mathrm{mg} / \mathrm{L}$ cadmium concentration (Table 3).

\section{Discussion}

As a result of cadmium application, there was a reduction in both species richness and total diatom population in all concentrations compared to the control group. The small-sized species, which were exposed to metal in algal communities, occupy the areas left by the other species in the community, thus showing that these species have a tolerance against metals, light conditions and different nutrient salts. Deniseger et al. [21] found a strong relation between the abundance increase of the small-sized species and the increase in the cadmium, copper and zinc concentrations that are the residues in waters. The Cocconeis placentula var. euglypta and Gomphonema minutum, which are dominant species in this study, were relatively smaller compared to the other diatoms. In addition, Gold et al. [22] reported a full and superficial adhesion on the macrophyte surface of the diatoms during cadmium applications in low concentration in their study conducted with the prephitic diatoms, but they stated that they preferred a finer adhesion at the poles with the high concentrations. Based on the increase in cadmium concentration, this made us think that the diatoms' position on the surface changed and they absorbed cadmium on almost all the surface areas. For this reason, total organism and diversity rapidly decreased due to the increase in concentration.

Because of cadmium, imbalances occur in the nutrient salt intake of the vegetal organisms [23]. This effect disrupts the cellular redox potential of the diatoms under the photosynthetic group. And as a result of this, reactive oxygen species (ROS) emerge [24]. The development of ROS causes a rapid accumulation of cadmium especially in the aquatic plants [25]. Thus, enzyme inhibition, DNA and RNA damages and oil peroxidation along with cell death occur as a result of oxidative stress [26]. We believe that these processes occur among the reasons for the species richness in diatoms and the sudden decline in total population. One of the reasons behind why small-sized species are durable may be that the ROS accumulation is much slower due to the surface-volume relation.

In terms of chlorophyll- $a$ contents, a gradual decrease was observed with every concentration examination $(p \leq 0.05)$ (Figure 2). In the study conducted by Zhou et al. [27], when they exposed Sedum alfredii to different concentrations of cadmium, they observed a decrease in chlorophyll- $a$ quantity, depending on the increase in cadmium, just as in our research. Many researchers have pointed to similar results related to the subject [28-29]. As is known, when the plants are exposed to cadmium, there is inhibition (chlorophyll-reductas) of some special enzymes that take charge in the chlorophyll biosynthesis [30]. In addition, it becomes difficult for the $\mathrm{Mg}^{2+}$ element, that makes up the centre atom of the pigment, and for the $\mathrm{Fe}^{2+}$ element, that are involved in the synthesis phase, to be included in the system [31]. This study concluded that the decrease in the chlorophyll quantity is higher than the decrease in the carotenoid quantity (Figure 2). This result is parallel with the above studies. From the point of carotenoids, even though they are indirectly involved in the protection of the chlorophyll varieties, it is known that there is an increase in the carotenoid quantity within the stress-causing environmental factors. In addition, another duty of the carotenoids is that they are a type of pigment in the plants that prevents chlorophyll oxidation. The increase in the carotenoid quantity in the especially in the 6ppm cadmium concentration may be the proof that it enables this increase in order to protect the chlorophyll pigments of the diatoms and to widen the tolerance range.

As a consequence, the epiphytic diatoms that are in relationship with the macrophyte floras, which are located in wetlands exposed the metal pollution, and use these macrophyte floras as a habitat have proven that they are small but an important building blocks in the performance of the floral system and also shown that they can be powerful biological indicators.

\section{References}

[1]. Aiken, S. G.; Newroth, P. R.; Wile, I. Can J Physiol Pharm 1979, 59, 201215.

[2]. Secmen, O.; Leblebici, E. Wetland Flora of Turkey and Cover Plant 1997, Ege University, Science Faculty, Publish No: 158. Ege University Press, İmir.

[3]. Ali, M. M.; Soltan, M. Aquatic Bot. 2006, 84, 239-244.

[4]. Ryan, M. W.; John, D. Hidrobiologica 2011, 665, 93-105.

[5]. Mackereth, F. J.; Heron, J. H.; Talling, J. F. Water Analiysis Some Revised Methods for Limnologists, Association Scientific Publications. U. K., 1989.

[6]. Dogan, M.; Saygıdeger, D. S. Ekoloji 2009, 18, 57-64.

[7]. Ayas, D.; Kalay, M.; Sangun, M. K. Ekoloji 2009, 18, 32-37.

[8]. Haghiri, F. J Environ Qual. 1973, 2, 93-96.

[9]. Sanchez, B. B., The use of antioxidant enzymatic activities of metal contamination in freshwater biofilms,Thesis. Universitat de Girona, Spain, 2008.

[10]. Potapova, M. G.; Charles, D. F.; Ponader, K. C.; Winter, D. M. Hydrobiologica 2004, 517, 25-41.

[11]. Koster, D.; Hubener, T. Int. Rev. Hydro. 2001, 86, 241-252.

[12]. Mitrofanova, E. Russ. J. Ecol. 2011, 3, 256-259.

[13]. Lototskaya, A. B.; Piet, F. M.; Costeb, V. M.; Vijver, B. V. Ecol. Indic. 2011, 11, 456-467.

[14]. Round, F. E. J. Ecol. 1953, 41, 174-97.

[15]. Krammer, K.; Lange Bertalot, H. Gustav Fischer-Verlag, Stuttgart Band, 2/3, 3, 1991a.

[16]. Krammer, K.; Lange Bertalot, H. Gustav Fischer-Verlag, Stuttgart Band, 2/4, 4, 1991b.

[17]. Krammer, K.; Lange Bertalot, H. Gustav Fischer-Verlag, Stuttgart Band, 2/1, 1, 1999a.

[18]. Krammer, K.; Lange Bertalot, H. Gustav Fischer-Verlag, Stuttgart Band, $2 / 2,2,1999 b$.

[19]. John, D. M.; Whitton, B. A.; Brook, A. J. The Freshwater Algal Flora of the British Isles, Cambridge University Press, 2003.

[20]. Margalef, R. Int. Rev. Hydrobiol. 1960, 45, 133-153.

[21]. Deniseger, J.; Austin, A.; Lucey, W. P. Freshwater Biol. 1986, 16, 209 218.

[22]. Gold, C. A.; Feurtet-Mazel, M.; Coste, A.; Boudou, A. Arch Environ Con Tox. 2003, 44, 189-197

[23]. Benavides, M. P.; Gallego, S. M.; Tomaro, M. L. Braz. J. Plant Physiol. 2005, 17, 21-34.

[24]. Romero, P.; Rodriguez, M. C.; Corpas, M.; Gomez, F. J.; Del Rio, M. Sandalio, L. A. Plant Cell Environ. 2004, 27, 1122-1134.

[25]. Sanitadi-Toppi, L.; Gabrielli, R. Environ Exp. Bot. 1999, 41, 105-130.

[26]. Mittler, R. Trends Plant Sci. 2002, 7, 405-410. 
[27]. Zhou, W.; Qiu, B. Plant Sci. 2005, 169, 737-745.

[28]. Caroline, G.; Agnes, F. M.; Michel, C.; Alain, B. Freshwater Biol. 2003, 48, 316-328.

[29]. Sabater, S.; Navarro, E.; Guasch, H. J Appl Phycol. 2002, 14, 391-398.

[30]. Van Assche, F.; Clijsters, H. Plant Cell Environ. 1990, 13, 195-206.

[31]. Clarkson, D.; Luttge, U. Progr. Bot. 1989, 51, 93-112. 